\title{
posterlistings
}

Each number is both the abstract number and the poster board number. Poster board numbers begin with 25. Posters are grouped in 7 categories:

$\begin{array}{lr}\text { Biochemical Genetics } & 25-33 \\ \text { Clinical Genetics } & 34-94 \\ \text { Cytogenetics } & 95-118 \\ \text { Education and Public Health } & 119-129 \\ \text { Genetic Counseling } & 130-140 \\ \text { Molecular Genetics } & 141-160 \\ \text { Perinatal Genetics } & 161-183\end{array}$

Within each category, posters are in alphabetical order by name of the first (presenting) author.

Exhibits and posters are located in the Oasis 3 Room of the Palm Springs Convention Center. Booths will be staffed and the poster area will be open and accessible as follows:
Friday, March 10: $\quad$ 11:45 am-1:00 pm Lunch will be sold in Oasis 3 .

5:00 pm-7:00 pm: Poster session with authors

5:00 pm-6:00 pm: Authors at oddnumbered boards

6:00 pm-7:00 pm: Authors at evennumbered boards

Saturday, March 11: 7:30 am-8:30 am

Complimentary continental breakfast in Oasis 3.

11:30 am-1:00 pm

Lunch will be sold in Oasis 3 .

Sunday, March 12: $\quad$ 8:00 am-12:00 pm

(posters only, no exhibits)

\section{Biochemical Genetics}

25 2-Methylbutyrl-CoA dehydrogenase deficiency: a new inborn error of L-isoleucine metabolism. Gibson KM, Burlingame T, Hogema B, Jakobs $C$, Schutgens RBH, Millington D, Roe $C$, Roe D, Sweetman L, Steiner RD, Linck L, Pohowalla P, Kiss D, Sacks $M$, Rinaldo P, Vockley J.

26 Neonatal cholestasis: new presentation of X-linked adrenoleukodystrophy. Gibson WT, Lepage G, Smith K, Moser $H$, Moser A, Mitchell GA.

27 Riboflavin responsive ethylmalonic encephalopathy in two Korean sibs. Hahn SH, Lee EH, Eun BL, Rinaldo P.

28 Severe Conradi-Hunermann syndrome (CDPX2) is a phenocopy of peroxisomal rhizomelic chondrodysplasia punctata (RCDP). Kronn D, Shapiro LR, Kelly R, Braverman $N$.

29 Methylmalonic aciduria, hyperhomocysteinemia, hematologic and/or neurologic abnormalities in 3 infants born to mothers with asymptomatic $\mathrm{B}_{12}$ deficiency. Nikkel $S M$, Mhanni A, Dilling L, Seargeant L, Stobart K, Rosenblatt D, Gorlin JB, Korson MS, Greenberg CR, Prasad C.

30 RadioHPLC profiles of acyl-carnitines improve detection of mild glutaric acidemia type II and short chain acyl-CoA dehydrogenase deficiency. Rhead WJ, Lambert $D$.

31 Vitamin $\mathrm{B}_{12}$-responsive methylmalonic aciduria due to a new inborn error of adenosylcobalamin synthesis, $c b l H$. Rosenblatt DS, Watkins D, Matiaszuk N.
32 Detection of carbohydrate deficient glycoprotein syndrome by capillary electrophoresis. Taylor HA.

33 Correction of the cystinotic phenotype in cultured cells by an aminoglycoside. Thoene J, Lemons $R$.

\section{Clinical Genetics}

34 Familial aortic aneurysms. Abuelo DN, Guo D, Cantu A, Carmical S, Milewicz D.

35 Clinical and molecular diagnosis of Nager syndrome in a preterm infant (27 week gestation): case report. Ahmed $M N$, Smith W, Koeberl DD, Qumsiyeh M, Lee B, Goldstein R.

36 BRCA1 and BRCA2 mutation analysis in at-risk African-American families: results and implications. Baumbach $L$, Gayol L, Scholl T, Basterrechea H, Pfeifer I, Davies J, Perera E, Smith S, Fernando Arena J.

37 Mitochondrial disease and disorders of energy metabolism: a recognizable pattern of systemic disease. Bay $C A, M a$ tika GL, Del Vecchio MA.

38 FGFR3 mutations K650N and K650Q cause hypochondroplasia. Bellus GA, Garber AT, Bryke CR, Weaver CA, Speiser PW, Webster MK, Donoghue DA, Francomano CA, Spector EB.

39 Knowledge and attitudes about carrier testing for hemophilia A among patients and their relatives. Callanan $N$, Jennings-Grant T, Lakon C, Spinney T, Sorenson JR. 
40 Unilateral congenital lymphedema with intestinal lymphangiectasia, elevated liver transaminases, and hypopigmentation. Campbell WM, Noel JM, Martin LS.

41 Clinical findings in mitochondrial neurogastrointestinal encephalomyopathy syndrome. Chacin JA, MartinezBasalo C, Pineda L, Gonzalez S, Morales de Machin A, Ramos N, Molina O, Soto I, Cardozo J, Castillo M.

42 Lethal Pallister-Killian syndrome and Fryns syndrome: diagnostic considerations. Clarkson KB, Corning K, Toburen A.

43 Rubinstein-Taybi syndrome with hepatoblastoma. Claus JA, Kousseff BG, Ranells JR, Jervis GA.

44 Scapuloiliac dystosis (Kosenow syndrome) spectrum: two additional cases. Elliott AM, Rimoin DL, Witt DR, Lachman RS.

\section{Withdrawn}

46 Say-Meyer syndrome: a new case with magnetic resonance imaging of the brain, cardiac abnormality and X-linked dominant inheritance pattern. Gottesman GS, SilhavyJA, Singh GK, Martin DS.

47 Minimal phenotypic findings of Down syndrome in a patient with true trisomy 21. Hajianpour MJ, Hajianpour $A K$, Sayar H, Manoochehri F, Mackie Ogilvie C.

48 Retinitis pigmentosa, growth hormone deficiency and acromelic skeletal dysplasia in two male siblings: possible familial RHYNS syndrome. Hedera P, Gorski JL.

49 Testing for the Jewish BRCA founder mutations in archived tissue. Hixon HEC, Scheuner MT.

50 Concordance among monozygotic and dizygotic twins from a population-based sample for self-reported atopic triad, syndrome x, and psychiatric conditions. Huang WY, Maier W, Murrelle L, Corey LA, Eaves LJ, Shepherd NS.

51 Oculoauriculofrontonasal syndrome in a 9-month-old male. Ishmael HA, Begleiter ML, Butler MG.

52 Cervical spine anomalies in Weaver syndrome: a diagnostic clue in adults. Kelly TE.

53 Evaluation of telemedicine use for clinical genetics services in Iowa. Keppler-Noreuil KM, Welch J, Sebille S, Grigsby J, Zollo $S$.
54 Identification of mitochondrial mutation (tRNA ${ }^{\text {lys }}$ ) and genetic counseling in a family with MERRF syndrome. Kim HJ, Park SJ, Ha MJ, Kim CW, Kim JS.

55 Clinical and molecular studies in a large unique family with limb-girdle muscular dystrophy and Paget disease of bone. Kimonis VE, Kovach MJ, Salam A, Leal S, Waggoner B, Davis $K$, Khardori R, Gelber $D$.

56 Microgastria in the genetic clinic. Kousseff BG.

57 New case of hepatic glycogen synthase deficiency: biochemical findings and comparison with reported cases. Laberge AM, Mitchell G, Van de Werve G, Lambert $M$.

58 Autosomal recessive syndrome due to amazing consanguinity. Lacassie Y, Avegno J, Tilton AH.

59 Ovarian cancer screening in women from hereditary breast/ovarian cancer families. Laframboise S, Nedelcu R, Murphy KJ, Cole DEC, Rosen B.

60 BRCAl mutation carrier with three breast primaries and childhood ionizing radiation treatments: possible gene/ environment interaction. Levonian PJ, Williams MS.

61 Ruvalcaba syndrome (a rare progeroid syndrome): new case and review of the literature. Martinez-Basalo C, Chacin JA, Gonzalez S, Marquez M, Castillo M, Levy-Bercowski D.

62 New genetic syndrome among the Old Order Amish of Smicksburg, PA. Matika GL, Del Vecchio MA, Bay CA.

63 Unique skeletal dysplasia with cataracts, ataxia, learning disability and mild facial dysmorphism. McLeod DR, Boag G, Trussell R, Skov C, Adams C.

64 Acrorenal-ectodermal dysplasia-lipoatrophic diabetes syndrome with focal segmental glomerulosclerosis. McPherson E.

65 Anonychia and absence of distal phalanges in a patient with apparently balanced $\mathrm{t}(17 ; 21)(\mathrm{q} 24.2 ; \mathrm{q} 11.2)$. McPherson $E$, Prosen T, Surti $U$.

66 Syndrome of ocular, skeletal and abdominal abnormalities. M'rad R, Mazzoul F, Belguith N, Ben Jemaa L, Smaoui N, Chaabouni $H$.

67 Genetic study of two Tunisian Ehlers-Danlos syndrome type VI. M'rad R, Maazoul F, Belguith N, Ben Jemaa L, Smaoui $N$, Chaabouni $H$. 
68 Withdrawn

69 Analysis of 70 adult patients referred for genetics evaluation. Novak S, Williams MS, Levonian PJ, Josephson KD, Williams $J L$.

70 Utility of both bone marrow and renal transplants in the management of individuals with Schimke immunooseous dysplasia. Petty EM, Castle VP.

71 Osteopetrosis, progressive sensorineural deafness, glaucoma, alopecia and cardiomyopathy in a 13-year-old female: new syndrome or mild variant of Yunis-Varon syndrome? Pletcher BA, Suslak L, Carruth SG, Kolor K, Boyd L.

72 Close relationship to Smith-Lemli-Opitz patients positively correlates with an increased incidence of high cholesterol, late-onset diabetes and infertility, and negatively correlates with alcoholism. Poss AF, Metherall JE, Opitz JM.

73 Circadian rhythm abnormalities of melatonin and haploinsufficiency of COPS3 in Smith-Magenis syndrome. Potocki L, Glaze D, Park S-S, Kasork CD, Shaffer LG, Tan D-X, Reiter RJ, Lupski JR.

74 Mutation in the CSB gene in a patient with cerebrooculo-facio-skeletal syndrome. Powell CM, Meira LB, Friedberg EC.

75 Craniosynostosis, ectopia lentis and congenital heart defect: further delineation of an autosomal dominant syndrome with reduced penetrance. Quercia NL, Teebi A.

76 Oral clefting, cartilaginous auricular malformations and other anomalies: a provisionally unique autosomal dominant syndrome. Roeder ER, Ali Khan-Catts Z, Fisher JH, DaackHirsch S, Murray JC, Curry CJR.

77 Incidence and severity of pain in Stickler and EhlersDanlos syndromes. Rose P, Davis J, Magyari T, Levy H, Francomano $C$.

78 Comparison of the Berlin and Gent nosologies in the diagnosis of Marfan syndrome: the NIH experience. Rose $P$, Levy H, Ahn N, Sponseller P, Magyari T, Davis J, Francomano C.

79 Molecular pathogenesis of Schmid metaphyseal chondrodysplasia. Savarirayan $R$, Freddi S, Keene DR, Rogers JG, Bateman JF.
80 Partial monosomy of chromosome 5 in two male siblings: phenotypic correlates. Schafer IA, Robin N, Clark B, Izumo S, Schwartz S.

81 BRCA testing uptake and participation in ovarian cancer prevention in women at risk for an inherited ovarian cancer susceptibility. Scheuner MT, Cheng LS-C, Hixon HEC, Rotter JI.

82 Marden-Walker syndrome: case report and review. Schweitzer DN, Earl DL, Graham JM Jr.

83 Natural history of the Adams-Oliver syndrome: a report of progressive central and peripheral nervous system involvement in a mother and son. Scribanu N, Foa $R$.

84 Sudden death in Proteus syndrome. Slavotinek AM, Vacha S, Peters K, Biesecker LG.

85 Severe Saethre-Chotzen syndrome in an infant with a complex chromosome rearrangement. Storm $A L$, Drumheller TC, Katz SN, Low J, Airheart C, Gripp KW, Curry C.

86 Seckel syndrome phenotype in a live-born with ring 4/monosomy 4 chromosomal mosaicism. Taylor MRG, Sujansky $E$.

87 Clinical manifestations of NFl in African-Americans and Caucasians. Tekin M, Bodurtha J, Korf B, Riccardi V.

88 Chiari I malformation associated with a P250R mutation of FGFR3. Terry L, Allen W, Schaefer F, Jewett $T$.

89 Acampomelic campomelic dysplasia with SOX9 mutation. Thong MK, Scherer G, Kozlowski K, Haan E, Morris L.

90 Early clinical features of Angelman syndrome in infants with chromosomal deletion of 15q11-q13. Tsai CH, Taylor M, Siegel-Bartelt J.

91 Spondyloepimetaphyseal dysplasia with multiple joint dislocations. Unger S, Savarirayan R, Cormier-Daire V, Cohn $D$, Wilcox W, Lachman RS, Rimoin DL.

92 Infant with trisomy 9 mosaicism and features of CHARGE association. Walker ME, Blough RI, Bove KE, Hopkin $R J$.

93 Third Prader-Willi syndrome phenotype due to maternal uniparental disomy 15 with mosaic trisomy 15 . Wulfsberg $E A$, Olander E, Stamberg J, Steinberg L. 
94 Phenotypic recognition of maternal (mosaic) and paternal (segmental) isodisomy for chromosome 14 without a Robertsonian translocation. Yang SP, Towner DR, Sherman $M P$, Shaffer LG, Johnson JP.

\section{Cytogenetics}

95 Double trisomy in spontaneous abortions: an 11-year review. Al-Kouatly HB, Johnson C, Skupski D, Lita Alonso M.

96 Case of 46,XX African American male. Asamoah A, Dev VG, Misra R, Onadeko O, Parsh B, Groening P.

97 Family with multiple chromosome anomalies. Dawson $A J$, Riordan D, Vust A, Konkin D, Wicksrom DE, Prasad C, Greenberg $C R$.

98 Can pericentric inversion and C-heterochromatin cause interchromosomal effect leading to an increased aneuploidy in sperm nuclei? Diukman R, Sardos Albertini F, Fejgin M, Shacham A, Amiel A.

99 Isochromosome 9p and choroid plexus papilloma: coincidence or cause? Fischer JM, Toriello HV.

100 Terminal deletion of $11 \mathrm{q}$ in two brothers: clinical, cytogenetic, molecular genetic and counseling issues. Haag $M M$, Phillips SM, Tunby ML, Beischel LS, McCann CL, Hansen JC, Johnson JP, Reynolds JF.

101 FISH delineation of multiple chromosome abnormalities in a mentally retarded patient with severe chronic disabilities. Harrison KB, Eddey G, Barabas G, Mintz J.

102 Electronic karyotype transmission. Harrison KB, Warburton D.

103 Molecular and cytogenetic analysis of Y; 1 familial translocation. Kim JW, Kang IS, Nam SA, Kim YM, Lee YS, Park SY.

104 Chromosomal nosology in referred populations. Kleyman SM, Mizhiritskaya V, Macera MJ, Verma RS.

105 Smith-Magenis syndrome diagnosed at birth. Lozzio C, Ryan T, Bamberger E, Holland E, Carter W.

106 Chromosome analysis of spermatozoa extracted from testes of men with nonobstructive azoospermia. Martin $R H$, Greene C, Rademaker A, Barclay L, Ko E, Chernos J.
107 Zeroing in on breakpoint susceptibility regions on chromosomes in breast carcinoma. Mattoo A, Verma RS.

108 Interphase spectral FISH: tailoring a diagnostic and minimal residual disease assay for oncology. Murata-Collins JL, Zhang F, Tcheurekdjian L, Slovak ML.

109 Ring chromosome 14 syndrome: prenatal diagnosis of two cases with 45,XY,-14/46,XY,r(14)(p11.2q32). Schmidt $R T$, Ravnan JB, Lamb AN, Weinstein ME.

110 Tandem duplication of bands q13.13q13.33 resulting in partial trisomy of long arm of chromosome 19. Sekhon GS, Johnson EB.

111 Maternal age-specific chromosomal abnormalities at amniocentesis. Shklovskaya T, Verma RS.

112 Severe growth retardation and limb anomalies in a boy with $47, \mathrm{XY},+\mathrm{r}(7)$ and maternal uniparental disomy for chromosome 7. Stadter CS, Stamberg J, Das S, Wulfsberg EA.

113 Double and triple trisomy in spontaneous abortions: an older maternal age and earlier gestational age than seen in single trisomies. Sullivan J, Yusef R, Marini T, Naeem R.

114 Further clinical and cytogenetic delineation in $1 \mathrm{p} 36$ deletion syndrome. Vargas $F R$, Ramos $M$, Goncalves-Neto JB, Martins RR, Ramos H, Llerena JC Jr, Cabral de Almeida JC.

115 Familial report of duplication 9p syndrome. Wenger $S L$, Borsa $V$, Holt $C D$, Hummel M, Mullet $M$.

116 Proximal 6q deletion phenotype: findings in de novo interstitial deletion 6q14.1q15. White BJ, Schwartz AT, Levin SW, Coll EJ, Anguiano A, Wang S, Yang X-J.

117 Tetraploidy in prenatal diagnosis: "cultural artifact" or clinical diagnosis? Winsor EJT, Chitayat D, Skidmore MB.

118 Partial monosomy $12 \mathrm{p}$ and ring chromosome 12 mosaicism in a male with developmental delay and mild dysmorphism. Yee HA, Chernos JE, Veale PM, Clarke ME, Graham GE.

\section{Education and Public Health Genetics}

119 The genetic counselor as a resource for families with a medical indication for cord blood banking. Epstein JM, Meyers R, Reed WF, Smith RS, Taylor K, Haaz S, Lubin BH. 
120 Public acceptance of an interactive kiosk to educate about folic acid to prevent neural tube defects. Jackson DN, Brown L.

121 Public's quest for genetic information: the role of a telephone helpline. Lander LE, Kramer EA, Davidson ME, Collins $D L$.

122 Factors affecting the incidence of Down syndrome live births in Illinois from 1989 to 1997. Leonard DR, Pergament E, Schmidt $H$, Egler $T$, Shen $T$.

123 The state of public health genetics in Rhode Island. Mark HFL, Caldarone R, Zimmerman A, Viner-Brown S, Simon $P$, Colt A, Hollinshead W, Nolan P.

124 Assessment of genetic knowledge and utilization among mental health care providers and consumers. Petty EM, Madeo $A C$, Smith LB, Milner KK.

125 MCHB SPRANS projects: collaborative efforts to guide primary care providers to access and use medical genetic information electronically. Proud V, Silvey K, Barash C, Pletcher B, Hanson N.

126 Ethical issues encountered in establishment of the Texas Birth Defect Research Center. Scheuerle A, Wright D.

127 BRCA genetic testing: where are physicians in the decision-making process? Velicer CM, Taplin S.

128 Evaluating data from newborn screening programs: Georgia, 1998. Wang SS, Fernhoff PM, Grinzaid K, Ramachandran M, Franko EA, Henson M, Buehler J, Khoury MJ.

129 Visual presentations at 1998 meeting suggest insensitivity of geneticists to a common genetic disorder. Williams MS, Williams JL.

\section{Genetic Counseling}

130 Attitudes regarding genetic counseling issues of the $\mathrm{Pa}$ kistani population at Maimonides Medical Center in Brooklyn. Barrett SK, Rosa DA, Begum S, Hafeez A, Kupchik GS.

131 Patient perspectives on the process of informed consent for DNA testing. Cytrynbaum C, Babul-Hirji R, Rowell M, Henderson K, Australie K, Druker H, Dupuis L, Quercia N, Shuman C, Kennedy S.
132 Genetic counseling for mitochondrial disorders. Del Vecchio MA, Matika GL, Bay CA.

133 Constructing rapport in televideo genetic counseling. Flore LA, Risinger ST, Britt DW, Zador IE, Gilbert AD, Evans MI, Johnson A.

134 Prenatal genetic counseling by telemedicine: a feasibility study. Flore LA, Risinger ST, Britt DW, Zador IE, Gilbert AD, Evans MI, Johnson A.

135 Practical use of three-dimensional imaging in genetic counseling: patient perception of usefulness as a counseling tool. Jackson DN, Brown L, Keel-Thompson K.

136 Prenatal diagnosis of fragile $\mathrm{X}$ syndrome: identification of a male fetus mosaic for a premutation on chorionic villus sampling-management and follow-up. Kennedy SJ, Wei C, Steele L, Teebi AS.

137 Interactive web-based genetic screening questionnaires in a primary care and obstetrics practice: pilot study. Neidich JA, Taswell C, Daniels $K$.

138 Genetic risk assessment in women over 35: natural pregnancies compared to assisted reproductive technology pregnancies. Pearson M, Neidich J.

139 Preconceived ideas about second trimester screening: a guide for counseling. Snow S, Souter V, Luthy D, Nyberg D.

140 Low maternal serum estriol as a marker for steroid sulfatase deficiency. Stanislaw $C L$, Rogers $R C$, Stewart $K$, Phelan $M C$.

\section{Molecular Genetics}

141 Sequence characterization of the $-{ }^{\mathrm{THAI}}$ allele of $\alpha$ thalassemia and rapid detection using a single-tube multiplex PCR assay. Chong SS, Boehm CD, Cutting GR, Higgs DR.

142 BRCA buccal immunoassay predicts BRCAl and BRCA2 mutations. Cohn GM, Byrne TJ, Hoffman DE, Adams LA, Lane MA, Reece MT.

143 Variant chromosome 1 reveals centromeric DNA sequences within the 1qh region. Conte RA, Verma RS. 
144 X-linked corneal dermoid maps to Xq24-Xter. Dar $P$, Javed AA, Pandita RK, Ben-Yishay M, Spiteri E, Ferreira JC, Gross SJ, Chitayat D, Edelman L, Morrow BE, Nitowsky HM.

145 Unexpected female patient within a classical LeschNyhan family. De Gregorio L, Nyhan WL, Serafin E, Chamoles NA.

146 Primary ciliary dyskinesia: search for the responsible genes through linkage and candidate gene approaches. DeLozier-Blanchet $C D$, Bartoloni L, Gehrig $C$, Radhakrishna $U$, Meeks M, Duriaux-Sail G, Maiti A, Guerne PA, Walt $H$, Gardiner RM, Antonarakis SE, Blouin JL.

147 Mitochondrial DNA mutations in Chilean patients with Leber hereditary optic neuropathy. Fadic $R$, Lobos $C$, Schweitzer M, Luco C.

148 Frequency and clinical significance of the S1235R mutation in the cystic fibrosis transmembrane conductance regulator gene: results from a collaborative study. Feldman GL, Monaghan KG, Barbaratto GM, Snow K.

149 Genome-wide linkage study for ossification of the posterior longitudinal ligament of the spine reveals a major susceptibility locus on chromosome 21q. Furushima K, Ikari K, Maeda S, Koga H, Takeda J, Harata S, Inoue I.

150 Novel nonsense mutation of the GTP cyclohydrolase I gene in a family with dopa-responsive dystonia. Hong KM, Kim YS, Paik MK.

151 Molecular analysis of chromosome $6 \mathrm{p}$ rearrangement in retinoblastoma. Imbert I, Coignet LJA, Pellestor F.

152 Williams syndrome: on the genetic basis of human cognition. Korenberg JR, Chen X-N, Hirota $H$, Lai Z, Bellugi $U$, Burian D, Roe B, Matsuoka R.

153 Locus for autosomal dominant renal Fanconi syndrome maps to the long arm of chromosome 15. Lichter-Konecki $U$, Broman KW, Dart R, Blau E, Konecki DS.

154 Detection of a de novo mutation in a family with SMA type I: the importance of dosage testing. McGowan-Jordan J, Zeesman S, Whelan DT, Ray PN, Stockely TL, Prior T, Carson $N L$.

155 Association of G-protein $\beta 3$ subunit $\mathrm{C} 825 \mathrm{~T}$ variant $(\mathrm{G} \beta 3 \mathrm{~S})$ and heart valve abnormalities in obese patients treated with fenfluramine-phentermine. Ning $L$, Eichelberger JP, Berk $B C, Q i M$.
156 CFTR mutations in Chilean patients with cystic fibrosis. Repetto GM, Flores I, Lobo C, Boza ML, Perez MA, Guiraldes E, Harris $P$, Sanchez I.

157 Withdrawn

158 Genetic testing for Niemann-Pick type $C$ disease. Snow $K$, Park WD, Lundquist PA, Walsh Vockley C, Patterson MC, Karnes PS, O'Brien JF.

159 HFE 5569A allele defines a low-risk haplotype for hereditary hemochromatosis. Somerville MJ, Sprysak KA, Hicks $M$, Elyas BG, Vicen-Wyhony L.

160 Mohr-Tranebjaerg syndrome is an X-linked recessive disorder characterized by mitochondrial dysfunction associated with neuronal cell death. Tranebjaerg L, Lindal S, Merchant S, Ingebretsen OC, Hamel B, Fung V, Hayes M, Koehler C, Nilssen $O$, van Ghelue $M$.

\section{Perinatal Genetics}

161 Clinical significance of isolated fetal echogenic bowel. Al-Kouatly HB, Chasen ST, Steltzoff J, Chervenak FA.

162 Is an elevated maternal serum $\mu \mathrm{E} 3 \mathrm{MoM}$ value in the second trimester associated with a poor pregnancy outcome? Aufox SA, Berry MN, Conrad D, Stamper TH, Hart PS.

163 Prenatal diagnosis of otocephaly. Brewer R, Dykhuizen $R$, Sumners $J$.

164 Prune belly syndrome in a patient with only a mildly distended bladder. Brewer R, Menzel M, Sumners J.

165 Pattern analysis for ultrasound anomalies in fetuses with normal karyotype. Farina A, Rizzo N, Pilu G, Caramelli E, Carinci $P$, Bovicelli $L$.

166 Extreme spectrum of Pallister-Hall syndrome. Greenly $\mathrm{KH}, \mathrm{Tyson} \mathrm{RW}$, Tsai $\mathrm{CH}$.

167 Evaluation of prenatal screening program for Down syndrome: analysis of 96 cases of Down syndrome for the last 10 years. Han JY, Kim MY, Ahn HK, Yang JH, Ryu HM, Kim JM, Kim YM, Park SY, Han HK, Lee YH, Kim ES.

168 Antenatal diagnosis of mixoploidy: a case report. Jackson DN, Brown L. 
169 Cystic lymphangioma of the axilla and chest wall. Jackson DN, Brown L.

170 Congenital mesoblastic nephroma: perinatal, surgical and genetic features and associated 2D and 3D imaging. Jackson DN, Haag M, Brown L, Keel-Thompson K, Phillips SM, Tunby M, Beischel LS, Bennett TL.

171 Sonogram findings with Brachmann-de Lange syndrome. Jervis GA, Kalter CS, Kousseff BG.

172 Recurrence of triploidy in a woman with low level 45,X mosaicism. Johnson LR, Blough RI, Miller ME.

173 Characteristics of fetuses with polyhydramnios and abnormal chromosome study. Lazebnik $N$.

174 Long-term follow-up of amniocentesis. Lebel $R R$, Manno MM.

175 Prenatal diagnosis of MIDAS/MLS syndrome associated with a deletion at Xp22.1. Marvin ML, Duquette DA, Hogge WA, Hunter Y, Toriello HV.

176 Prenatal and postmortem features of a case of RitscherSchinzel syndrome. Nikkel SM, Levi CS, Menticoglou S, Phillips $S$, Safneck J, Chodirker BN.
177 Relationship between the Glu298Asp and intron 4 polymorphisms of endothelial nitric oxide synthase in an Hispanic population with preeclampsia. Pellicena A, Riskin-Mashiah S, Hefler LA, Gregg AR.

178 Outcomes of a prenatal cytogenetic screening program in an urban state university medical center. Powell EM, Santolaya-Forgas J, Matheson JKB, Shulman LP.

179 Prominent amnion-chorion separation between 13 and 15 weeks' gestation is associated with increased risk for fetal chromosome abnormalities. Shulman LP, Patel S, Phillips OP.

180 Withdrawn

181 Do X-or Y-chromosome bearing spermatozoa compete with older eggs in humans? Verma RS, Shklovskaya T, Baheig $S M$.

182 Fetal methotrexate syndrome. Wheeler $M E$, Stanford $M$, O'Meara P.

183 Prevalence of methylenetetrahydrofolate reductase C677T polymorphisms in Northwest Louisiana newborn population. Yanamandra K, Napper D, Jalanivich DW, Thurmon TF. 